
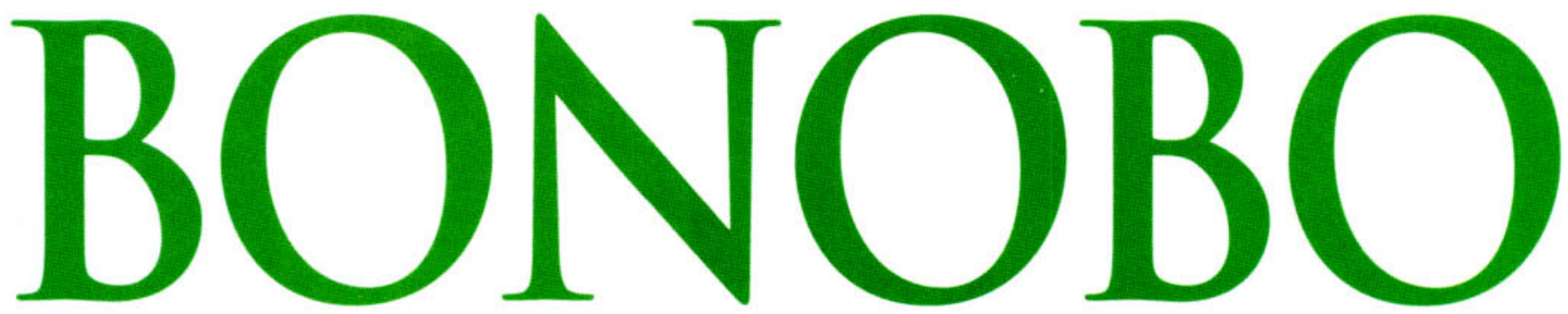

T H E F O R G O T T E N A P E

PHOTOGRAPHS

FRANS DE WAAL FRANS LANTING

U N I VERSITY OF CALIFOR NIA PRES S

Berkeley Los Angeles London 


\section{Copyright Page}

University of California Press

Berkeley and Los Angeles, California

University of California Press, Ltd.

London, England

Photographs (ㅇ 1997 Frans Lanting unless otherwise credited. Photos on pages 50, 69, 92-93, and 182-183 appear courtesy of the National Geographic Society.

(ㄷ) 1997 by

The Regents of the University of California

First paperback edition 1998

Library of Congress Cataloging-in-Publication Data

Waal, F. B. M. de (Frans B. M.), 1948-

Bonobo : the forgotten ape / Frans de Waal ; photographs, Frans Lanting.

p. $\mathrm{cm}$.

Includes bibliographical references and index.

ISBN 0-520-21651-2 (pbk. : alk. paper)

1. Bonobo. 2. Bonobo-Behavior. I. Lanting.

Frans. II. Title.

QL737.P96W3 1997

$599.88^{\prime}{ }_{44-\mathrm{dc} 20}$

96-41095

Printed in Hong Kong

$\begin{array}{lllllllll}9 & 8 & 7 & 6 & 5 & 4 & 3 & 2 & 1\end{array}$

This book is printed on acid-free paper. 